activity may be limited. Unwanted effects, reflecting its central and autonomic nervous system activity, include insomnia, nervousness, dry mouth, constipation, and excessive sweating. These would not induce toxicity and it seems in our case that mazindol's anorexic activity caused the intoxication.

${ }^{1}$ Schou M, Baastrup PC, Grof P, et al. Pharmacological and clinical problems of lithium prophylaxis. $B r \mathcal{F}$ Psychiatry 1970;116:615-9.

${ }^{2}$ Dempsey M, Dunner DL, Fieve RR, Farkas I, Wong J. Treatment of excessive weight gain in patients taking lithium. Am $\mathcal{f}$ Psychiatry $1976 ; 133(9): 1082-4$

${ }^{3}$ Furlong FW. Lithium toxicity occurring with a "reducing" diet. Can Psychiatr Assoc F 1973;18:75-6.

${ }^{4}$ Hansen HE, Amdisen A. Lithium intoxication (Report of 23 cases and review of 100 cases from the literature). $Q 7 \mathrm{Med} 1978 ; 47(186): 123-44$

5 Defelice EA, Chaykin LB, Cohen A. Double-blind clinical evaluation of mazindol, dextroamphetamine and placebo in treatment of exogenous obesity. Curr Ther Res 1973;15:358-66.

(Accepted 16 fanuary 1980)

Department of Medicine, Basingstoke District Hospital, Basingstoke, Hants RG24 9NA

M S HENDY, MRCP, registrar

A F DOVE, MB, CHB, registrar

P G ARBLASTER, FRCP, consultant physician

\section{Intravenous methylprednisolone in minimal change nephrotic syndrome}

Prendisone by mouth in large doses usually reverses minimal change nephrotic syndrome but there may be severe side effects, particularly in patients with frequent relapses. We therefore tried a new regimen beginning with three consecutive pulses of intravenous methylprednisolone and following these with prednisone by mouth in low doses.

\section{Case reports}

Eleven patients aged from 4 to 46 were admitted to the study. All had a nephrotic syndrome defined on the basis of hypoalbuminaemia $(\leqslant 25 \mathrm{~g} / \mathrm{l})$ and proteinuria $\left(\geqslant 40 \mathrm{mg} / \mathrm{m}^{2} / \mathrm{h}\right.$ ). Renal biopsy specimens from seven patients by light and electron microscopy showed minimal glomerular changes. All patients had highly selective proteinuria as assessed by the clearances of IgG and transferrin. Remission was defined as three consecutive days without proteinuria and relapse as finding proteinuria $\left(\geqslant 4 \mathrm{mg} / \mathrm{m}^{2} / \mathrm{h}\right)$ on three consecutive examinations within seven days. Patients were classified as frequent relapsers if they relapsed more than once within six months of their first response or four times within any one year. ${ }^{1}$

Methylprednisolone $(15-20 \mathrm{mg} / \mathrm{kg})$ was given intravenously over $20-30$ min every $24 \mathrm{~h}$ for three consecutive days. After this prednisone $\left(20 \mathrm{mg} / \mathrm{m}^{2} / 24 \mathrm{~h}\right)$ was given by mouth for four weeks. The dose was then reduced to $20 \mathrm{mg} / \mathrm{m}^{2}$ every other day. This continued for five months and then progressively tapered off and stopped. In patients who relapsed the regimen was restarted.

All the patients had a complete remission, generally within 10 days (table). Three relapsed after 28,180 , and 380 days. They responded to a new course of intravenous methylprednisolone and had no further relapses. Two patients complained of flushing during methylprednisolone infusion, but it ceased a few minutes after the infusion stopped. No sign of hypercorticism, infections, or other complications referable to corticosteroids were observed.

\section{Comment}

Treatment with $60 \mathrm{mg} / \mathrm{m}^{2} /$ day prednisone by mouth for a few weeks may obtain a remission of the nephrotic syndrome in most patients with lipoid nephrosis. This regimen is generally well tolerated but signs of hypercorticism may develop. Moreover, many patients relapse and treatment has to be lengthy, increasing the risk of severe side effects and even death. ${ }^{2}$ On the other hand, patients with frequent relapses respond abnormally to ACTH. ${ }^{3}$ This suppression of the hypothalamic-pituitary-adrenal axis, possibly induced by protracted prednisone treatment in high dosage, might promote a relapse. The best schedule of steroid administration in lipoid nephrosis is therefore still uncertain.

The urine became protein free in all our patients and a remission was reached even in frequent relapsers. Three patients with heavy proteinuria in relapse rapidly responded to further treatment with intravenous methylprednisolone. None of our patients suffered from hypercorticism or other side effects. These preliminary results seem to indicate that our regimen might be effective and well tolerated in most patients with lipoid nephrosis.

${ }^{1}$ Abramowicz M, Arneil GC, Barnett HL, et al. Controlled trial of azathioprine in children with nephrotic syndrome. A report of the international study of kidney disease in children. Lancet 1970;i:959-61.

2 Arneil GC, Lam CN. Long-term assessment of steroid therapy in childhood nephrosis. Lancet 1966;ii:819-21.

${ }^{3}$ Leisti S, Hallman N, Koskimies O, Perheentupa J, Rapola J, Vilska J. Association of postmedication hypocortisolism with early first relapse of idiopathic nephrotic syndrome. Lancet 1977;ii:795-6.

(Accepted 27 November 1979)

Divisione di Nefrologia e Dialisi, Via della Commenda 15, Ospedale Policlinico, 20122 Milano, Italy

CLAUDIO PONTICELLI, $M D$, chief of unit

ENRICO IMBASCIATI, MD, assistant in nephrology

NADIA CASE, $M D$, assistant in nephrology

Divisione di Nefrologia e Dialisi, Via Palagi 9, Ospedale M Malpighi, 40138 Bologna, Italy

PIETRO ZUCCHELLI, $M D$, professor of medicine and chief of unit LEO CAGNOLI, MD, assistant in nephrology SONIA PASQUALI, MD, assistant in nephrology

\section{Oral contraceptives and pituitary adenomas}

An association between oral contraception and prolactin-secreting pituitary adenomas has been suggested by several recent studies. Sherman et al, ${ }^{1}$ for example, reported that 30 out of 42 women with amenorrhoea and hyperprolactinaemia who were surgically treated for a pituitary adenoma had taken oral contraceptives for an average of 2.4 years. Hardy et $a l^{2}$ found that 60 out of 80 patients with surgically proved prolactinoma had used oral contraception. Reports such as these prompted us to examine the relevant data accumulated in the two major British prospective surveys of women using oral contraception-namely, the Royal College of General Practitioners' (RCGP) study and the Oxford/Family Planning Association (FPA) study. Both of these studies began in 1968 and have been described elsewhere. ${ }^{3}{ }^{4}$

Results in 11 patients with minimal change nephrotic syndrome treated with modified corticosteroid regimen

\begin{tabular}{|c|c|c|c|c|c|c|c|}
\hline Case No & $\begin{array}{l}\text { Age (years) } \\
\text { and sex }\end{array}$ & $\begin{array}{c}\text { Episode of } \\
\text { nephrotic syndrome }\end{array}$ & Response to treatment & $\begin{array}{c}\text { Duration of } \\
\text { remission (days) }\end{array}$ & Relapse & $\begin{array}{c}\text { Response to } \\
\text { treatment }\end{array}$ & $\begin{array}{c}\text { Duration of } \\
\text { remission (days) }\end{array}$ \\
\hline $\begin{array}{r}1 \\
2 \\
3 \\
4 \\
5 \\
6 \\
7 \\
8 \\
9 \\
10 \\
11\end{array}$ & $\begin{aligned} 9 \mathrm{M} \\
11 \mathrm{M} \\
8 \mathrm{~F} \\
12 \mathrm{M} \\
22 \mathrm{~F} \\
46 \mathrm{~F} \\
5 \mathrm{M} \\
4 \mathrm{M} \\
16 \mathrm{M} \\
22 \mathrm{M} \\
12 \mathrm{M}\end{aligned}$ & $\begin{array}{c}\text { Frequent relapser } \\
\text { Frequent relapser } \\
\text { First } \\
\text { Frequent relapser } \\
\text { Second } \\
\text { First } \\
\text { First } \\
\text { First } \\
\text { Frequent relapser } \\
\text { Second } \\
\text { First }\end{array}$ & $\begin{array}{l}\text { Remission } \\
\text { Remission } \\
\text { Remission } \\
\text { Remission } \\
\text { Remission } \\
\text { Remission } \\
\text { Remission } \\
\text { Remission } \\
\text { Remision } \\
\text { Remission } \\
\text { Remission }\end{array}$ & $\begin{array}{l}700 \\
380 \\
455 \\
180 \\
270 \\
28 \\
230 \\
210 \\
180 \\
150 \\
150\end{array}$ & $\begin{array}{l}\text { No } \\
\text { Yes } \\
\text { No } \\
\text { Yes } \\
\text { No } \\
\text { Yes } \\
\text { No } \\
\text { No } \\
\text { No } \\
\text { No } \\
\text { No }\end{array}$ & $\begin{array}{l}\text { Remission } \\
\text { Remission } \\
\text { Remission } \\
\text { = } \\
\text { = } \\
\text { - }\end{array}$ & $\begin{array}{l}\overline{300} \\
\frac{180}{240} \\
= \\
= \\
=\end{array}$ \\
\hline
\end{tabular}


Clinical details of five cases of pituitary adenoma

\begin{tabular}{|c|c|c|c|c|c|c|}
\hline Patient & Date of birth & Oral contraceptive use & Presentation & Diagnosis & HPL & Treatment \\
\hline $\begin{array}{l}1 \\
2 \\
3\end{array}$ & $\begin{array}{l}8 \text { December } 1934 \\
8 \text { August } 1923 \\
29 \text { March } 1937\end{array}$ & $\begin{array}{l}\text { Nil } \\
\text { July 1968-Jan } 1976\end{array}$ & $\begin{array}{l}\text { Infertility } 1968 \\
\text { Visual field defect } 1976 \\
\text { Amenorrhoea } 1970 \text {. Amenorrhoea and } \\
\text { galactorrhoea } 1971\end{array}$ & $\begin{array}{l}\text { Acromegaly } 1969 \\
\text { Chromophobe adenoma } 1976 \\
\text { Pituitary adenoma } 1975\end{array}$ & $\begin{array}{l}\text { Not known } \\
\text { No } \\
\text { Yes }\end{array}$ & $\begin{array}{l}\text { Surgery } \\
\text { Continued observation } \\
\text { Surgery }\end{array}$ \\
\hline $\begin{array}{l}4 \\
5\end{array}$ & $\begin{array}{l}27 \text { October } 1937 \\
9 \text { December } 1939\end{array}$ & $\begin{array}{l}\text { Nil } \\
\text { 1967-June } 1969\end{array}$ & $\begin{array}{l}\text { Secondary amenorrhoea } 1965 \\
\text { Amenorrhoea and galactorrhoea } \\
1971 \text { and } 1973\end{array}$ & $\begin{array}{l}\text { Cystic chromophobe adenoma } 1972 \\
\text { Pituitary adenoma } 1973\end{array}$ & $\begin{array}{l}\text { Not known } \\
\text { Not known }\end{array}$ & $\begin{array}{l}\text { Surgery } \\
\text { Radiotherapy }\end{array}$ \\
\hline 6 & 18 September 1936 & $1965-75$ & Amenorrhoea and galactorrhoea 1976 & Pituitary adenoma 1977 & Yes & Bromocriptine \\
\hline
\end{tabular}

HPL $=$ Hyperprolactinaemia

\section{Studies and results}

The table gives clinical details of the five cases of pituitary adenoma (patients 1-5) reported during the course of the RCGP study and the one (patient 6) reported during the Oxford/FPA study. Patient 2 was taking an oral contraceptive when the pituitary adenoma was diagnosed and patient 5 was a former user. Patients 1,3 , and 4 had never taken an oral contraceptive. The respective periods of observation in the study for current users, former users, and never-users of oral contraceptives were 67990,42622 , and 111252 woman-years. Patients 1 and 4 had had subfertility problems before recruitment to the study and so were not "at risk" of being recruited as oral contraceptive users. They should therefore be excluded from the comparison with the user group. On the other hand, about a quarter of the whole study control group used no form of contraception at the time of recruitment. Many of these subjects may also have had fertility problems and should be similarly excluded from the respective period of observation. With the small number of cases reported here, however, such detailed analysis would not be informative. Patient 6 was recruited in the Oxford/FPA study in the oral contraceptive group (period of observation 69468 woman-years) but had stopped taking a contraceptive pill before her pituitary adenoma was diagnosed. The periods of observation in the other two groups in the study, consisting of women who used a diaphragm or an IUD, were 31735 and 22799 woman-years respectively.

\section{Comment}

While no reasonable assessment of incidence can be made from the few observations reported here, the data suggest that there is no substantial increase in the occurrence of pituitary adenomas associated with oral contraceptives. In neither study is there reason to believe that any diagnosed cases have been missed, and perhaps uncontrolled selective hospital-based studies give an exaggerated impression of the frequency of an association. The clinical details in this report show that the temporal relationship between the diagnosis of pituitary adenoma and oral contraceptive use is complex. The findings in the only case-control study reported to date ${ }^{5}$ are in line with our results in that no association between prior use of oral contraceptives and pituitary tumour was detected. Coulam et $a l^{5}$ suggest that the increasing incidence of pituitary tumours that they noted in women of childbearing age is more likely to be due to recent advances in screening methods and surgical procedures than to the use of oral contraceptives. Our own observations point to a similar conclusion, but studies with more extensive data are desirable.

${ }^{1}$ Sherman BM, Horris CE, Schlechte J, et al. Pathogenesis of prolactinsecreting pituitary adenomas. Lancet 1978 ;ii:1019-21.

${ }^{2}$ Hardy J, Beauregard H, Robert F. Prolactin-secreting pituitary adenomas: transsphenoidal microsurgical treatment. In :Robyn C, Harter M, eds. Progress in prolactin physiology and pathology. Netherlands: ElsevierNorth Holland, 1978:361-9.

${ }^{3}$ Royal College of General Practitioners. Oral contraceptives and health. London: Pitman Medical, 1974.

${ }^{4}$ Vessey M, Doll R, Peto R, Johnson B, Wiggins P. A long-term follow-up study of women using different methods of contraception-an interim report. F Biosoc Sci 1976;3:373-427.

${ }^{5}$ Coulam CB, Annegers JF, Abboud CF, Laws ER, Kurland LT. Pituitary adenoma and oral contraceptives: a case-control study. Fertil Steril $1979 ; 31: 25-8$.

(Accepted 15 fanuary 1980)

Royal College of General Practitioners, Manchester Research Unit, 8 Barlow Moor Road, Manchester M20 0TR

SALLY J WINGRAVE, BA, MIBIOL, research assistant

CLIFFORD R KAY, MD, FRCGP, director

University of Oxford, Department of Social and Community Medicine, Oxford OX1 3QN

MARTIN P VESSEY, MD, FRCPED, professor

\section{Instructions to authors}

The following are the minimum requirements for manuscripts submitted for publication.

A stamped addressed envelope or an international reply coupon must accompany the manuscript if acknowledgment of its receipt is desired.

(1) Typing should be on one side of the paper, with double or triple spacing between the lines and $5-\mathrm{cm}$ margins at the top and left-hand side of the sheet.

(2) Three copies should be submitted.

(3) Spelling should conform to that of Chambers Twentieth Century Dictionary.

(4) References must be in the Vancouver style (BMF, 24 February 1979, p 532) and their accuracy checked before submission.

(5) SI units are used for scientific measurements. In the text they should be followed by traditional units in parentheses. In tables and illustrations values are given only in SI units, but a conversion factor must be supplied. For general guidance on the International System of Units, and some useful conversion factors, see The SI for the Health Professions (WHO, 1977).

(6) Authors should give their names and initials, their current appointments, and not more than two degrees or diplomas. Each author must sign the covering letter as evidence of consent to publication.

(7) Letters to the Editor submitted for publication must be signed personally by all the authors.

(8) Acknowledgments will not be sent unless a stamped addressed envelope or an international reply coupon is enclosed.

(9) Detailed instructions are given in the $B M \mathcal{F}$ dated 5 January 1980 (p 6). 